\title{
Seedling establishment in eelgrass: seed burial effects on winter losses of developing seedlings
}

\author{
Scott R. Marion*, Robert J. Orth \\ Virginia Institute of Marine Science, College of William and Mary, Gloucester Point, Virginia 23062, USA
}

\begin{abstract}
Constraints on the transition of seeds to seedlings have the potential to control plant dispersal and persistence. We investigated the processes leading to low initial seedling establishment in eelgrass Zostera marina through a manipulative field experiment assessing the relative importance of germination failure and seedling loss during the winter. Seed plots were established in October at 3 unvegetated sites in the Chesapeake Bay (USA) region, with seeds either at the sediment surface or buried at 2 to $3 \mathrm{~cm}$. Emerging seedlings were monitored at 6 wk intervals between December and April using a video camera, and seed germination was tracked in separate destructively-sampled plots. Sediment height change was measured, and sediment disturbance depth was estimated by deploying cores layered with tracer particles and examining tracer loss upon core retrieval. We found a low rate of seedling establishment 6 mo after seeding $(1.2,3.8$, and $2.8 \%$ for surface seeds at the 3 sites) that was largely due to seed and seedling loss rather than to germination failure, with $90 \%$ of seeds retrieved after December having germinated. Seed burial significantly enhanced seedling establishment at 2 of 3 sites $(40.4,16.8$, and $10.3 \%$ establishment for buried seeds). Seed loss occurred mostly within the first month of the experiment, and was most severe for seeds at the sediment surface. Indicator core results showed widespread disturbance of sediments to depths that could have dislodged early seedlings developing from surface seeds, and to a lesser degree seedlings from buried seeds. Our findings help identify the nature and timing of a substantial $Z$. marina seedling establishment bottleneck in our region, and show that some of the key processes pivotal to $Z$. marina recruitment dynamics and optimal restoration strategies involve physical sediment-seedling interactions rather than seed germination.
\end{abstract}

KEY WORDS: Seagrass - Recruitment limitation - SAV restoration - Sediment disturbance . Wave energy $\cdot$ Germination $\cdot$ Seed burial

\section{INTRODUCTION}

The transition of seeds to successfully established seedlings is a complex ecological process that has the potential to control plant dispersal and persistence (Harper 1977). For prolific seed-producing plants with high dispersal potential such as the seagrass Zostera marina (eelgrass), this transition can be a crucial but poorly understood stage. For many plants, predation, pathogens, and inadequate nutrient reserves contribute to high rates of seed loss, with few seeds surviving to the seedling stage (Clark et al. 2007). Once seeds germinate, early-stage seedlings are subject to additional abiotic stresses such as extremes in temperature, moisture, or nutrients. In aqueous environments, waves and currents can erode sediments and dislodge emerging seedlings or smother seedlings under sediment deposits (Koch et al. 2006, 2010), and sediment characteristics can also limit developing rhizomes (Handley \& Davy 2002). Identifying the factors limiting the seed to seedling transition is critical to understanding plant demographic processes and developing seed-based restoration techniques.

Seagrasses, marine angiosperms, are unique among the flowering plants because they live entirely sub- 
mersed, pollination is hydrophilous, and there are no obvious pollinators (Ackerman 2006). Seagrasses are also threatened around the world because of their susceptibility to anthropogenic changes in water quality, with reported declines rivaling marshes and mangroves (Waycott et al. 2009). As conservation efforts increasingly direct attention toward achieving adequate water quality for healthy seagrass, more attention is focusing on restoring seagrass (Paling et al. 2009). With interest in restoration shifting toward use of seeds in appropriate areas, a fundamental knowledge of the processes influencing seagrass seed survival and seedling establishment is essential.

Eelgrass Zostera marina is widely distributed in the North Atlantic and Pacific Oceans (Green \& Short 2003). Flowering and seed production are related to increasing springtime water temperatures (Setchell 1929, Silberhorn et al. 1983), and seeds are released either directly from the plant to the sediment surface or can be dispersed meters to kilometers from the parent plant on floating air bubbles or on detached flowering shoots (Churchill et al. 1985, Harwell \& Orth 2002). Most seeds do not move far from where they initially settle (Orth et al. 1994), but beyond that fact, the processes controlling subsequent seedling establishment are relatively poorly understood.

In the US mid-Atlantic region, Zostera marina seeds have been used to study dispersal patterns and processes (Orth et al. 1994, Luckenbach \& Orth 1999, Harwell \& Orth 2001) and have been used to initiate recovery of $Z$. marina in coastal lagoons (Orth et al. 2012 , this Theme Section [TS]) that were devoid of $Z$. marina since the 1930s 'wasting disease' pandemic. These studies identified a consistently low rate of seedling establishment, finding that generally less than $10 \%$ of seeds deployed in September or October transitioned to seedlings surviving 6 mo (Orth et al. 2003, Marion \& Orth 2010a). In contrast, laboratory experiments have demonstrated a much higher potential recruitment, with 80 to $95 \%$ of seeds typically germinating (R. Orth unpubl. data). Very few field observations of seedlings have been made between germination in November or December, and April, when rapid seedling growth in the warming waters allows easier observation than is possible for small seedlings (less than $5 \mathrm{~cm}$ ) during the cold of winter. Churchill (1983) reported on a progressive loss of $Z$. marina seedlings in containers under field conditions from the time of germination in the fall to late spring but did not document the processes leading to their loss. Moore et al. (1993) documented high wintertime germination of most $Z$. marina seeds contained in above-ground enclosures, but no direct observations of germination rates (as opposed to seedling establishment rates) for unprotected seeds in sediment under field conditions are available. The proportion of seeds that might remain in sediments without germinating (germination failure) was unknown.

We hypothesized that sediment disturbance at sandy sites with low sediment cohesion could be an important mechanism of loss of early-stage seedlings, and sought to document sediment dynamics (accumulation/erosion events and depth of disturbance) associated with seedling development at multiple field sites. The work presented here addressed the processes leading to low seedling establishment in unvegetated sediments through a field manipulative experiment during the winter, a period largely ignored in Zostera marina ecology. Specifically, we addressed the following 4 questions: (1) Does germination failure limit initial seedling establishment? (2) What proportion of developing seedlings is lost during the winter? (3) Is seedling loss associated with measurable sediment re-suspension or net changes in sediment height? (4) Does seed burial reduce the subsequent loss of developing seedlings?

\section{MATERIALS AND METHODS}

\section{Study sites}

The study was conducted at 3 sites in the US midAtlantic region that had a history of Zostera marina presence. Two were within the lower Chesapeake Bay (Piankatank River, $37.503^{\circ} \mathrm{N}, 76.329^{\circ} \mathrm{W}$ and Mumfort Island in the York River, $37.268^{\circ} \mathrm{N}, 76.515^{\circ} \mathrm{W}$ ) and a third was located in Spider Crab Bay $\left(37.358^{\circ} \mathrm{N}\right.$, $75.800^{\circ} \mathrm{W}$ ), one of the coastal bays that are part of the Virginia Coast Reserve Long-Term Ecological Research site. The 2 Chesapeake Bay sites have been devoid of $Z$. marina since a bay-wide dieback after Hurricane Agnes in 1972 (Orth \& Moore 1983). The coastal bay site lost $Z$. marina in the early 1930s in a North-Atlantic-wide pandemic wasting disease outbreak (Rasmussen 1977), but is now slowly recovering as a result of a large-scale re-seeding project (Orth et al. 2012). All 3 sites have been used in previous seed experiments (Orth et al. 2003, Marion \& Orth 2010a), with Spider Crab Bay generally showing higher seedling establishment rates than the 2 Chesapeake Bay sites. All sites were between 0.5 and $0.9 \mathrm{~m}$ water depth (mean low water, MLW), with the Spider Crab site the deepest at $0.9 \mathrm{~m}$. Tidal range was approximately $0.4 \mathrm{~m}$ at the Piankatank River 
site, $0.7 \mathrm{~m}$ at the Mumfort Island site, and $1.2 \mathrm{~m}$ at the Spider Crab Bay site. Maximum near-bottom currents at the Mumfort Island site are approximately $20 \mathrm{~cm} \mathrm{~s}^{-1}$ (Orth et al. 1994), and spring-tide currents at the Spider Crab Bay site have been measured at similar velocities (S. Marion unpubl. data). Currents at the Piankatank River site were unmeasured, but diver observations over multiple years suggest substantially lower maximum currents than at the other 2 sites.

\section{Germination failure for surface and buried seeds}

To assess the contribution of seed germination failure to low seedling establishment rates, we established 32 seed plots at each site on 4, 22, and 25 October 2007 at the Mumfort Island, Piankatank River, and Spider Crab Bay sites, respectively. The $20 \mathrm{~cm}$ diameter circular plots $\left(0.03 \mathrm{~m}^{2}\right)$ were separated by $10 \mathrm{~m}$ and marked by PVC stakes to allow precise relocation and seed retrieval. Stakes were offset by $0.5 \mathrm{~m}$, and protruded only $5 \mathrm{~cm}$ from the sediment. At each site, 16 surface-seed plots were established by placing 50 seeds on the sediment surface and gently pressing them into the sediment with a $1 \mathrm{~mm}$ sieve, covering them with approximately 1 to $2 \mathrm{~mm}$ of sand. This technique was intended to prevent immediate horizontal transport of the seeds by currents during the following tidal cycle. Sixteen additional plots were created with 50 seeds buried at a target depth of 2 to $3 \mathrm{~cm}$ by injecting seeds into the sand using a handheld plastic pipette with the opening cut to approximately $3 \mathrm{~mm}$ diameter. Groups of 10 to 15 seeds were drawn into the pipette, then slowly injected into the sediment with the pipette tip inserted to a calibrated depth at an angle of $30^{\circ}$, while the pipette was pulled at approximately $2 \mathrm{~cm} \mathrm{~s}^{-1}$ through the sediment maintaining the target planting depth. This process was repeated until all 50 seeds were planted. Preliminary trials during the development of this technique showed reliable planting in the target 2 to $3 \mathrm{~cm}$ depth range. All seeds used were individually assessed as viable seeds exhibiting an intact seed coat, high density, and rapid fall velocity in seawater (Marion \& Orth 2010b). Plots were placed in 2 rows along a $210 \mathrm{~m} \times 10 \mathrm{~m}$ constant-depth region parallel to the shoreline at each site, and were divided into 4 blocks for sampling. We interspersed surface-seed and buried-seed treatments along each row to ensure equal exposure to any undetected along-shore gradients in energetic regime or sediment conditions.
At 4 approximately 45 d intervals after planting, corresponding to mid-day low tide periods, 1 surfaceseed plot and 1 buried-seed plot were destructively sampled from each block. Sampling dates were 4, 10, and 11 December 2007; 18, 22, and 23 January 2008; 3, 4, and 6 March 2008; and 11, 16, and 18 April 2008. Water temperatures during the 4 sampling periods were $8-10^{\circ} \mathrm{C}, 3-5^{\circ} \mathrm{C}, 7-10^{\circ} \mathrm{C}$, and $14-15^{\circ} \mathrm{C}$, respectively. Sediments were removed to a depth of $15 \mathrm{~cm}$ in a square $0.9 \mathrm{~m} \times 0.9 \mathrm{~m}$ area incorporating the original $0.03 \mathrm{~m}^{2}$ plot, and were sieved through a $1 \mathrm{~mm}$ sieve to retrieve all seeds. We used a $30 \mathrm{~cm}$ wide square-sided scoop to remove sediment, and separately processed sediment from the central $0.09 \mathrm{~m}^{2}$ area (a single, central scoop) in order to detect whether any seeds had moved from the original plot into the adjacent area. We chose to use a scoop slightly larger than the original plot area to allow for any imprecision in relocating or sampling the central area. Divers also surveyed a $1 \mathrm{~m}$ wide area around each plot for any seedlings. Recovered seeds were counted and classified as germinated (split seed coat and obvious hypocotyl extension) or ungerminated. Two-factor analyses of variance (ANOVAs) were used to assess the effects of month and depth on seed recovery for each site separately. Following results indicating a possible month $\times$ depth interaction $(\mathrm{p}<$ 0.15), separate 1-way ANOVAs were run assessing the effect of month at each depth.

\section{Seedling loss for surface and buried seeds}

To quantify loss rates through the winter for developing seedlings, we created 12 plots at each site that were repeatedly, non-destructively sampled at the same intervals described above. Each $0.25 \mathrm{~m}^{2}$ plot received 200 seeds, either at the surface $(6$ plots) or buried (6 plots) as described above. Plots were placed in a single row parallel to the germination plot rows, with surface and buried plots alternating along the row to ensure that the 2 treatments had similar exposure to any undetected gradients in wave energy or sediment dynamics. Fixed PVC stakes protruding less than $5 \mathrm{~cm}$ from the sediment surface, offset from the corners of the seed plots by $10 \mathrm{~cm}$, allowed precise repositioning of a quadrat with $25 \mathrm{~cm}^{2}$ cells. A video camera was moved systematically over the grid, recording the position of all seedlings. In the lab, the tape was reviewed to produce a map of seedlings. The use of video reduced the inaccuracies related to direct recording of data by divers struggling with cold water tempera- 
tures, and allowed detailed matching of individual seedling positions between sampling periods by reference to the previous video tape if necessary. By April, many seedlings had developed multiple shoots, making it impossible to distinguish individual seedlings in the video footage. Therefore, we gently removed the sediment above the rhizome layer and counted seedlings directly in the field. Divers also surveyed a $1 \mathrm{~m}$ wide area around each plot for any seedlings.

Repeated-measures ANOVAs were used to assess the effects of month and depth on seedling abundance for each site separately. Data for December were omitted from analyses, as seedlings had not yet emerged from most plots.

\section{Sediment disturbance depth}

Sediment disturbance depth was estimated by deploying tracer particles at known depths concurrently with seed distributions, and later examining the depth distribution of recovered tracer particles. Layered cores containing tracer particles at $1 \mathrm{~cm}$ intervals ('indicator cores') were created in an $8 \mathrm{~cm}$ diameter, $15 \mathrm{~cm}$ tall plastic tube using sediments collected from each experimental site. Tracer particles were flat plastic sequins with unique shapes at each discrete depth layer (e.g. circles at $1 \mathrm{~cm}$, squares at $2 \mathrm{~cm}$ ). The tracer particles were intended to wash away if sediments were momentarily resuspended by storm waves, thereby leaving a record of scouring depth that could not be obtained by periodic sediment surface height measurements. Twelve cores were divided among 3 blocks located between the 4 blocks of germination plots described above, and were precisely located by offset markers to allow accurate re-sampling. Cores within blocks were separated by $10 \mathrm{~m}$, and blocks were separated by $50 \mathrm{~m}$, the width of 1 block of germination plots. Indicator cores were installed by first extracting a sediment core of the same depth from inside a slightly larger concentric tube, preventing the collapse of sediment into the evacuated space. The indicator core, with its bottom surface held in the core tube by a layer of weak tape, was installed with its surface sediments level with the surrounding bottom. The outermost tube was removed, then the indicator core sediments were held in place by an $8 \mathrm{~cm}$ diameter plunger while the core's tube was withdrawn, breaking the tape seal at the bottom and leaving the tracer particle layers buried at $1 \mathrm{~cm}$ intervals below the surface. In addition to the indicator cores, 3 poles with inscribed height marks were deployed to assess net deposition or erosion. The poles were driven as far as possible into the substrate to ensure that they remained stationary, and were located within the 3 blocks of indicator cores.

On each sampling date, 1 indicator core was removed from each block. The original core tube was inserted into the sediment, the top of the tube sealed with a rubber stopper, and the core removed and returned to the lab for analysis. A plunger was used to slowly extrude the core in $0.5 \mathrm{~cm}$ intervals, and tracer particles in each interval were identified and counted. The depth of each tracer particle layer from the sediment surface in the recovered core was used to calculate 2 metrics of sediment change, since the depth of each layer at installation was known. The difference between the known installation depth and the recovery depth of intact tracer layers (i.e. those with abundant particles maintaining well-defined horizontal bands) was interpreted in $0.5 \mathrm{~cm}$ intervals as the net change in sediment height. For example, square tracer particles were deployed in the $2.0 \mathrm{~cm}$ deep layer, so if a layer of square particles was recovered in the $3.0-3.5 \mathrm{~cm}$ deep layer, we scored the net change in sediment height as $+1.0 \mathrm{~cm}$; this reflects our choice to score $0 \mathrm{~cm}$ change for tracer layers found in the $0.5 \mathrm{~cm}$ interval below their depth at installation, rather than the $0.5 \mathrm{~cm}$ interval above, to compensate for any slight compaction of cores that might have occurred after installation. All undisturbed layers from 1 core reflected the same net change in sediment height, so multiple layers were used in scoring. The second metric, disturbance depth, was defined as the installation depth of the deepest tracer layer from which almost all deployed particles were missing at retrieval. For the previous example, if the layer of circular particles installed at $1.0 \mathrm{~cm}$ was missing, disturbance depth would be $1.0 \mathrm{~cm}$. This example illustrates the ability of our indicator core method to detect multiple events that first scour sediments deeply and later leave accumulated sediments that might otherwise be interpreted as only sediment deposition. Our estimate of disturbance depth is conservative, as disturbance could have extended almost to the next lower tracer particle layer.

Net change in sediment surface height was also measured against the permanent height reference poles on each sampling date. To avoid effects of erosion at the base of each pole, a $1 \mathrm{~m}$ bar placed on the sediment surface was used to estimate the integrated local surface height. 


\section{RESULTS}

\section{Seed germination test plots}

Seeds retrieved from independent germination test plots at monthly intervals showed little evidence of germination failure for either surface seeds or buried seeds (Fig. 1). Of all seeds retrieved in the January, March, and April samplings, 90\% had germinated

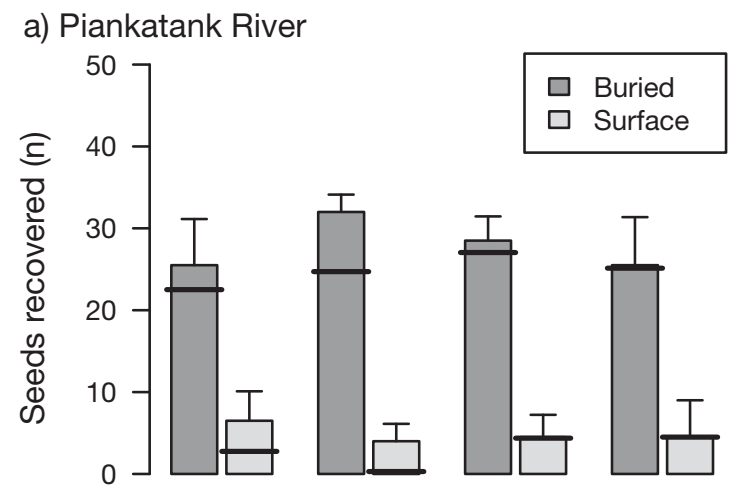

b) Mumfort Island

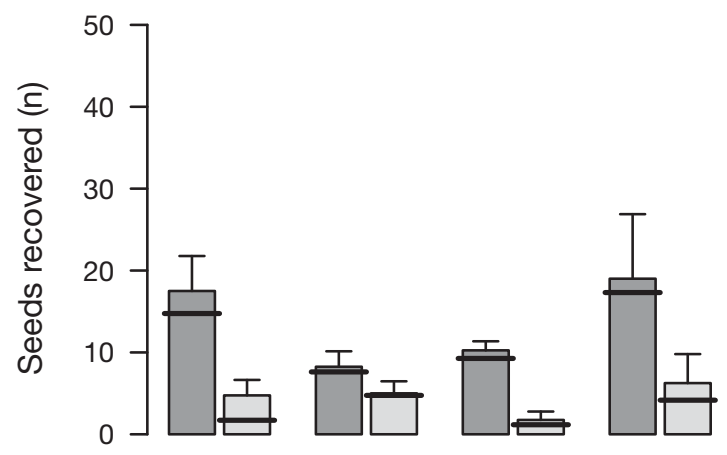

c) Spider Crab Bay

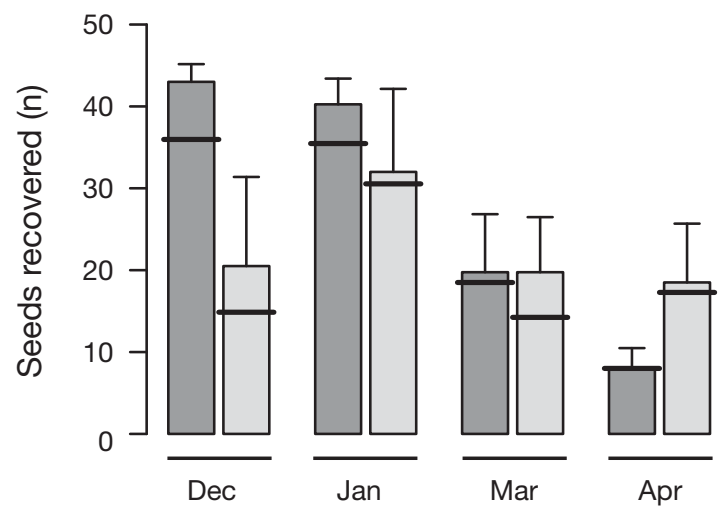

Fig. 1. Zostera marina. Mean number of seeds (+SE) recovered out of 50 deployed in $0.03 \mathrm{~m}^{2}$ germination test plots $(\mathrm{n}=$ 4). Buried seeds were injected to a depth of 2 to $3 \mathrm{~cm}$, while surface seeds were pressed 1 to $2 \mathrm{~mm}$ into the sediment surface by a $1 \mathrm{~mm}$ sieve. Horizontal lines through bars indicate the mean number of recovered seeds that had germinated
(December was excluded because germination was likely not complete by that point), and the proportion was similar for both buried and surface seeds. However, most surface seeds were lost from plots before retrieval $(90,91$, and $55 \%$ of all deployed seeds at the Piankatank River, Mumfort Island, and Spider Crab Bay sites, respectively). Significantly fewer buried seeds $(44 \%)$ were lost at the Piankatank River (2-way ANOVA, $\mathrm{df}=1,24 ; \mathrm{p}<0.0001$ ) and at Mumfort Island $(73 \% ; \mathrm{df}=1,24 ; \mathrm{p}<0.001)$. At Spider Crab Bay, $45 \%$ of buried seeds were lost, not significantly fewer than for surface seeds $(p=0.31)$. Most seeds were lost between plot establishment in October and the first sampling in December, and there were no significant effects of month on seed loss except for buried seeds at Spider Crab Bay (1-way ANOVA, df = 3,12; p < 0.001 ), where the seed germination plots may have been scoured by filamentous algae accumulating on seedlings or on nearby PVC stakes in March (see description in 'Video-monitored seedling plots' below). Variation in seed loss among the 4 replicate plots was high, especially at Spider Crab Bay, with individual plots showing excellent seed retention and others complete loss. Over $90 \%$ of retrieved seeds were found within the central $0.09 \mathrm{~m}^{2}$ scoop at all 3 sites, with the remainder found in the adjacent peripheral scoops.

\section{Video-monitored seedling plots}

In plots with seeds deposited at the sediment surface, monthly video monitoring through the winter showed moderate initial seedling abundance (approximately $15 \%$ of seeds deposited) followed by substantial seedling loss at the Piankatank River and Spider Crab Bay sites (Fig. 2a,c). At the Mumfort Island site, few seedlings (approximately $2 \%$ of seeds deposited) were observed in most surface-seeded plots, except for 1 plot positioned in a region of sediment accretion (see sediment analysis in 'Sediment disturbance depth' below) that showed $19 \%$ seedling emergence (Fig. 2b). Very few seedlings were observed in the surveyed region surrounding each video plot. Repeatedmeasures ANOVAs showed significantly greater seedling abundance in plots with seeds buried at 2 to $3 \mathrm{~cm}$ than in surface-seed plots at the Piankatank River ( $\mathrm{df}=1,10 ; \mathrm{p}<0.0001)$ and Mumfort Island sites $(\mathrm{df}=1,10 ; \mathrm{p}=0.016)$. No significant effects of month or interactions were detected at those sites. At Spider Crab Bay, the effect of seed depth was non-significant ( $\mathrm{df}=1,10 ; \mathrm{p}=0.095)$, but seedling abundance declined significantly over time for both depths $(\mathrm{df}=$ 
a) Piankatank River

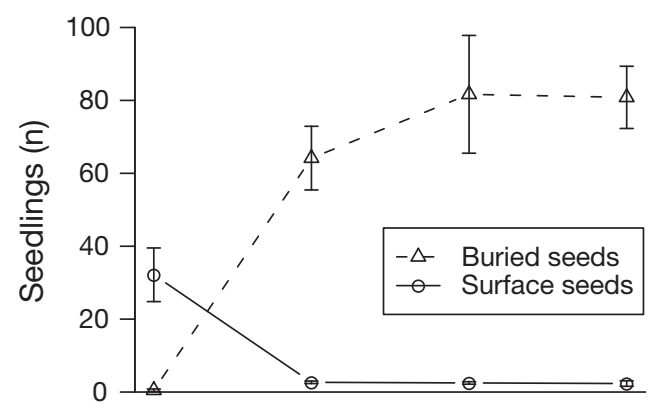

b) Mumfort Island

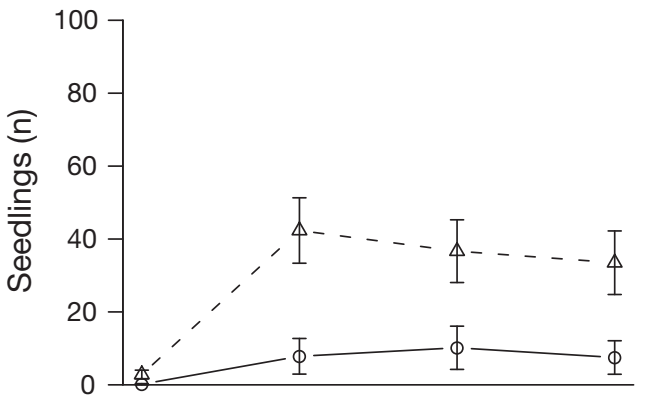

c) Spider Crab Bay

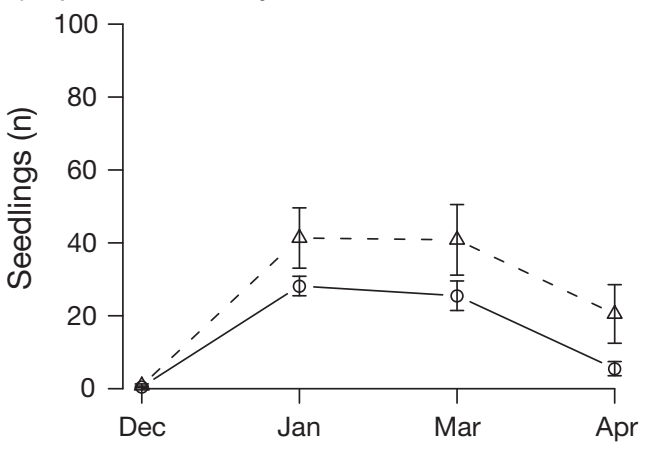

Fig. 2. Zostera marina. Mean number of seedlings ( $\pm \mathrm{SE}$ ) observed in repeated observations of $0.25 \mathrm{~m}^{2}$ video-monitored plots $(n=6)$ receiving 200 seeds each. Buried seeds were injected to a depth of 2 to $3 \mathrm{~cm}$, while surface seeds were pressed 1 to $2 \mathrm{~mm}$ into the sediment surface by a $1 \mathrm{~mm}$ sieve

$2,20 ; \mathrm{p}<0.0001)$. Seedling loss after the peak month was less severe for buried seeds $(1,21$, and $50 \%$ of mean peak seedling abundance lost at the Piankatank River, Mumfort Island, and Spider Crab Bay sites, respectively) than for surface seeds $(93,26$, and $80 \%$ ). Overall 6 mo seedling establishment rates at the same sites were $1.2,3.8$, and $2.8 \%$ for surface seeds, and 40.4, 16.8, and $10.3 \%$ for buried seeds.

Spider Crab Bay was influenced in March and April by an overgrowth of the filamentous brown alga Ectocarpus, which coated much of the bottom and most of the emerging seedlings. In April, many algal-covered seedlings had exposed rhizomes and were retained in the sediment only by root hairs.
Divers observed algal-covered, barely-attached seedlings being nearly dislodged by wave motion. Masses of macroalgae had also accumulated on nearby PVC stakes used to delineate plots, resulting in some scouring of the bottom and loss of seedlings. Macroalgae were not observed at the other sites.

\section{Sediment disturbance depth}

Indicator core results showed widespread disturbance of sediments to depths that could have dislodged early seedlings developing from surface seeds, and to a lesser degree seedlings from buried seeds (Fig. 3). Substantial variability in disturbance depth and net sediment height change was observed within sites and across sampling periods. In many cases, disturbance of the $1 \mathrm{~cm}$ deep tracer layer was evident despite net sediment accretion during the time period. Half of all Mumfort Island and Piankatank River cores showed sediment disturbance to at least $1 \mathrm{~cm}$ (Fig. 3b), and the depth of disturbance was deeper than net sediment loss in all cores (Fig. 3a). Different cores at the Mumfort Island and Piankatank River sites showed deposition and erosion within the same time period, suggesting sediment movement within sites rather than deposition or erosion across a whole site during a given time period. At Spider Crab Bay, no cores recorded any net sediment loss or sediment disturbance. Where net sediment accumulation was documented, it ranged from 0.5 to $3 \mathrm{~cm}$.

Net sediment height change measured against permanent reference poles showed high variability within sites (Fig. 4) and was not well correlated with height change recorded in nearby indicator cores (Fig. 3a). Of 33 possible pairs of core versus pole observations within the same block for the same time period ( 3 cores did not provide reliable sediment height change data), 20 differed by less than $2 \mathrm{~cm}$, but 5 differed by $5 \mathrm{~cm}$ or more. These pairs were due to individual poles at Mumfort Island and Piankatank River with substantial sediment accumulation, and 2 poles at Spider Crab Bay with sediment loss that was not reflected in nearby indicator cores.

\section{DISCUSSION}

Our experiments tracking germination, emergence, and loss of Zostera marina seedlings through the winter months revealed that seed loss and postgermination seedling loss, rather than germination 
failure, were responsible for a low rate of seedling establishment observed 6 mo after seeding. Seed loss generally occurred within the first month of the experiment, and was most severe for seeds at the sediment surface. Seed burial did not have a detectable effect on germination rates, as germination rates were similarly high for seeds at the surface and for buried seeds, but burial clearly enhanced the subsequent survival of emerging seedlings. Our findings help clarify the mechanism and general timing of a substantial $Z$. marina seedling establishment bottleneck for seeds that escape summertime seed predation in our region, demonstrating that the processes pivotal to $Z$. marina recruitment dynamics in unvegetated sediments involve physical sediment-seedling interactions rather than germination failure. They also demonstrate the potential utility of seed burial for maximizing seedling yield from limited seed supplies in Z. marina restoration efforts.

\section{Role of seed burial}

Seed burial has generally been viewed as important mostly for minimizing seed predation in terrestrial and submersed angiosperms (Fishman \& Orth 1996, Hulme \& Borelli 1999, Christian \& Stanton 2004). In the Chesapeake Bay region, seeds distributed in October have shown higher establishment rates than seeds present in the summer (Marion \& Orth 2010a) when seed predators are abundant and active (Fishman \& Orth 1996), and seed burial
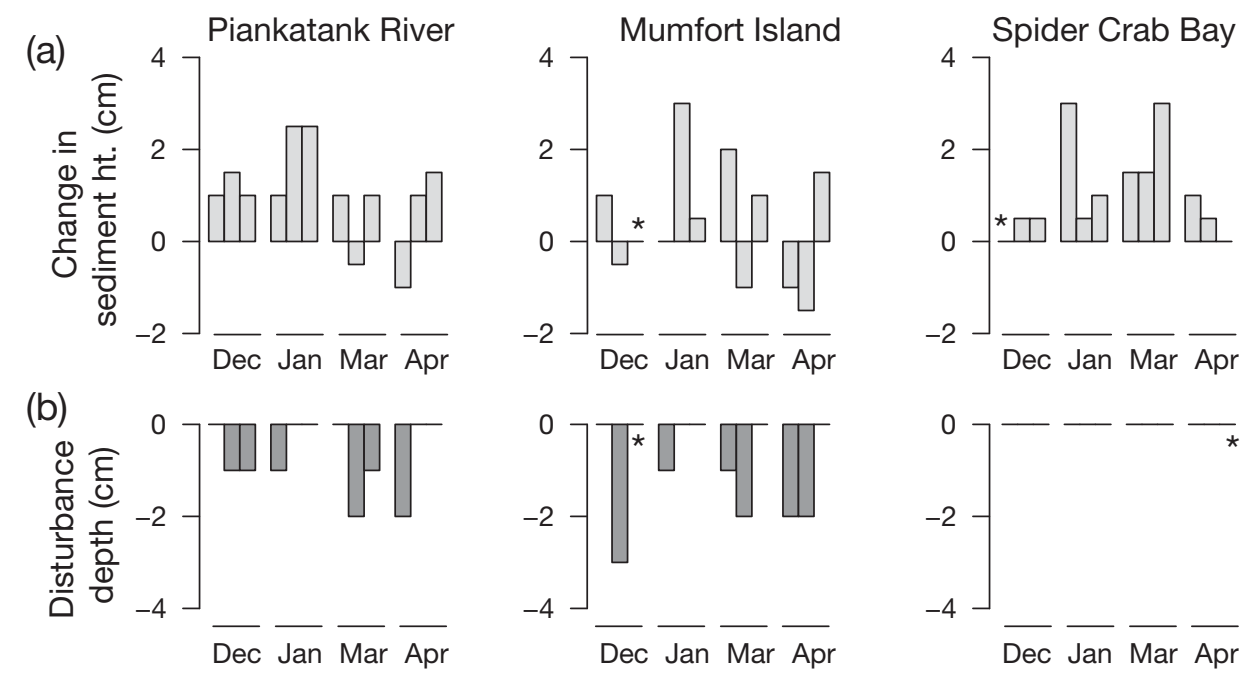

Fig. 3. Sediment changes recorded in cores with tracer particles layered at $1 \mathrm{~cm}$ intervals. Each bar shows 1 core, with cores from the left, center, and right sections of the experimental region shown in that order within each month. Asterisks indicate no data for an individual core. (a) Net sediment height change between core establishment in October and the indicated month. (b) Depth of sediment disturbance inferred from missing tracer particles in the same cores as in (a)
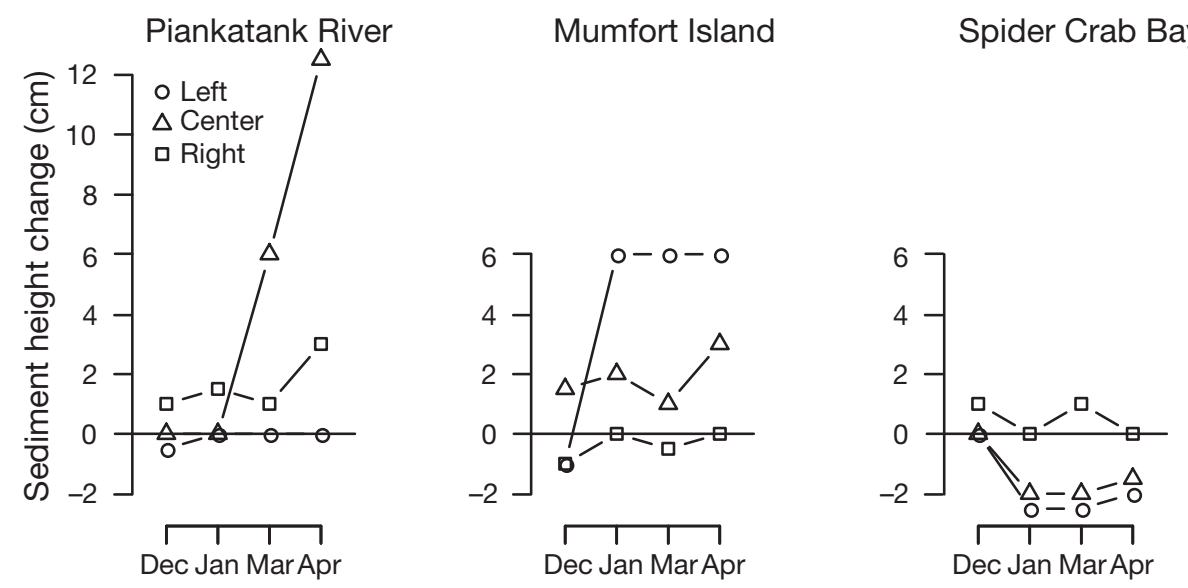

Fig. 4. Sediment height changes recorded against permanent poles deployed in the left, center, and right sections of the experimental region 
Table 1. Sediment grain size distribution and organic content at the experimental sites in the Chesapeake Bay area (USA). Mean (SD), $\mathrm{n}=3$

\begin{tabular}{|lccc|}
\hline Site & $\%$ Sand & $\%$ Silt+clay & $\begin{array}{c}\% \text { Organic } \\
\text { content }\end{array}$ \\
\hline Mumfort Island & $96.6(0.6)$ & $3.4(0.6)$ & $0.62(0.00)$ \\
Piankatank River & $98.6(0.5)$ & $1.4(0.5)$ & $0.73(0.07)$ \\
Spider Crab Bay & $86.2(4.6)$ & $13.8(4.1)$ & $1.41(0.36)$ \\
\hline
\end{tabular}

increased success for seeds present in summer (Marion \& Orth 2010a). In addition to reducing the potential for seed predation, our results show that seed burial benefits Zostera marina by reducing seedling loss after germination. While seed predators may have removed some surface seeds in our plots, their activity was likely reduced during our winter study compared to previous work on seed predation conducted during the warmer months, and our finding of substantial survival for surface seeds even into January at the site with potentially the most seed predators, Spider Crab Bay (Fig. 1c), suggests limited influence of predation on our results. More importantly, the observed pattern of disturbance depths of tracer particles suggests that physical forces (waves and currents) were responsible for removal of shallow seeds and seedlings. These physical processes are potentially also important for seed dispersal and seedling retention in other submerged macrophytes (Koch et al. 2010).

Some previous data exist suggesting a direct seed burial effect on germination (Granger et al. 2000, Tanner \& Parham 2010), and our results from seedburied plots in December showing a high proportion of germinated seeds are consistent with a seed burial effect on germination (Fig. 1), although variability in the number of seeds recovered and the proportion germinated was high, especially for Spider Crab Bay. However, our results for surface seeds are also consistent with the findings of Moore et al. (1993) that seeds held in oxygenated conditions in the field germinated later than seeds in anoxic conditions, but eventually reached similar, high germination rates. We think that the initial sampling in December reflected delayed germination of viable surface seeds, and suggest that the subtle pattern of higher proportions of germinated seeds found in later months resulted from the eventual germination of most seeds, rather than progressive loss of ungerminated seeds over time.

Seedling establishment rates for buried seeds at the Mumfort Island and Piankatank River sites were substantially higher than for surface seeds, and were the highest we have ever recorded for any seeds at these sites. Burial conferred relatively less of an advantage to seeds at the Spider Crab Bay site, where surface seeds performed much better than surface seeds at other sites. This is consistent with previous observations of higher broadcast seed success in the coastal bays and attenuated seed burial effects relative to Chesapeake Bay sites (Orth et al. 2003, Marion \& Orth 2010a). The higher initial retention of seeds and seedlings at Spider Crab Bay is likely a result of that site's finer sediment grain size and higher organic content (Table 1), which may provide a more consolidated foundation for anchoring developing seedlings and reduce erosion around developing shoots (Titus \& Hoover 1991). Spider Crab Bay was the only site with potential sources of extraneous seeds; these potential sources were 0.4 ha plots seeded 2 yr prior, with the closest plots either $480 \mathrm{~m}$ in the direction of tidal current flow, or $250 \mathrm{~m}$ perpendicular to the current. Our interspersed treatments would have been robust to any bias due to extraneous seed input, which we consider unlikely based on diver observations of minimal seedling abundance in the meter surrounding each plot. The few seedlings that were found outside plots were likely from seeds that moved out of the plots, not seeds arriving from external sources.

\section{Seed loss and germination}

The germination status of the seeds lost from germination test plots is unknown. Missing surface seeds in the $0.03 \mathrm{~m}^{2}$ germination test plots could have been uncovered and transported out of the $0.81 \mathrm{~m}^{2}$ sampling area, or they could have germinated in situ and subsequently been scoured out by waves. Since $90 \%$ of the retrieved seeds were found within the central $0.09 \mathrm{~m}^{2}$ sampling area, and divers examining the area surrounding the plots found very few seedlings, local seed redistribution does not seem to explain the patterns observed. Previous experiments have repeatedly found very few seedlings farther than $2 \mathrm{~m}$ from the point of seed deposition on the surface (Orth et al. 2003), and in the present experiment, the 'surface' seeds were covered by a few millimeters of sediment, reducing the likely importance of pregermination seed redistribution.

Instead, we hypothesize that many surface seeds germinated and were later scoured out. Results from the Piankatank River video-monitored plots show earlier leaf emergence for surface seeds than for buried seeds, and provide a clear example of sub- 
stantial, early shallow seedling loss. Earlier emergence is consistent with shallower seedling position in the sediment, and with exposure to a longer period of potentially erosive storm waves. Despite the early loss of many seeds, the data from recovered seeds show that relatively few seeds remain ungerminated in situ through the winter.

Although wave data at the sites are unavailable, we examined wind records from the nearest available weather station to assess storm events that might have differentially affected our sites during each sampling period (Table 2). We restricted data to winds blowing onshore for the Mumfort Island and Piankatank River sites, but used all data for the Spider Crab Bay site, which has no nearby protective shoreline. Differences in shoal width and fetch make direct comparisons among sites difficult, but the site with the greatest October to December seed retention in surface plots, Spider Crab Bay, had very high exposure to winds over 25 knots during that period. Comparison among sampling periods within sites shows the greatest duration and intensity of strong onshore winds at Mumfort Island in January to March, and in December to January at the Piankatank River. The early loss of surface seeds at these sites is therefore not parsimoniously explained by the timing of storm events; instead, we think the vulnerability of early-stage, shallow seedlings resulted in high losses in the first sampling period.

\section{Video-monitored seedling plots}

The video technique used to follow seedling development and loss through the winter was effective at documenting net seedling loss rates. Our estimates of

Table 2. Number of hours with mean wind speed exceeding specified thresholds $(20,25$, and 30 knots) for each sampling interval between Zostera marina seeding in October and final seedling assessment in April. Wind data from the nearest available NOAA CO-OPS stations (http://tidesandcurrents.noaa.gov) were used, and only onshore winds were included (160-310 for Mumfort Island, $310-140^{\circ}$ for Piankatank River, all directions for Spider Crab Bay)

\begin{tabular}{|c|c|c|c|c|c|c|c|c|c|}
\hline \multirow[b]{2}{*}{ Interval } & \multicolumn{3}{|c|}{$\begin{array}{l}\text { Mumfort } \\
\text { Island }\end{array}$} & \multicolumn{3}{|c|}{$\begin{array}{c}\text { Piankatank } \\
\text { River }\end{array}$} & \multicolumn{3}{|c|}{$\begin{array}{c}\text { Spider Crab } \\
\text { Bay }\end{array}$} \\
\hline & $>20$ & $>25$ & $>30$ & $>20$ & $>25$ & $>30$ & $>20$ & $>25$ & $>30$ \\
\hline Oct-Dec & 14 & 3 & 0 & 10 & 0 & 0 & 180 & 65 & 8 \\
\hline Dec-Jan & 10 & 2 & 0 & 21 & 2 & 0 & 149 & 49 & 18 \\
\hline Jan-Mar & 22 & 7 & 1 & 6 & 1 & 0 & 149 & 44 & 5 \\
\hline Mar-Apr & 17 & 7 & 2 & 12 & 1 & 0 & 202 & 45 & 10 \\
\hline
\end{tabular}

seedling emergence are likely conservative because there may have been some undetected loss of seedlings offset by newly emerged seedlings between observation time points, especially early in the study. For seeds placed at the sediment surface, seedling establishment rates at 6 mo were generally consistent with our low historical expectations (overall mean of $2.6 \%$ ), and also consistent with patterns of low establishment at the Mumfort Island and Piankatank River sites and higher establishment in the coastal bays (Marion \& Orth 2010a). While surface seeds at Mumfort Island produced very few seedlings except in 1 anomalous plot, the low April seedling counts at the Piankatank and Spider Crab sites clearly reflect loss of previously germinated seedlings, rather than germination failure.

\section{Sediment disturbance depth}

The indicator core technique used to estimate sediment disturbance depth and net sediment height change is a novel approach for documenting the physical processes expected to influence Zostera marina seeds and seedlings. Bioturbation can profoundly influence sediment biogeochemistry and particle movement, especially seeds (Dumbauld \& Wyllie-Echeverria 2003, Meysman et al. 2006). However, we think that disturbance by bioturbation was substantially lower than would be expected during the warmer months, as we found very few organisms in recovered cores and saw little evidence of burrowers and other sediment disruption in and around experimental plots.

Sediment height change recorded in indicator cores is expected to be more reliable than that recorded against protruding stakes, because stakes can cause local deposition or provide attachment sites for macroalgae that can subsequently scour sediments. Any bias in the core-derived measure is expected to be positive (more apparent sediment accumulation) due to the potential for compaction of the layered core. There is some evidence for this process, as intact tracer particle layers recovered near the bottom of cores were in some cases separated by slightly less than $1 \mathrm{~cm}$ upon retrieval, suggesting compaction during transport. The mean sediment height changes measured by cores were accumulations of 0.5, 1.0, and $1.2 \mathrm{~cm}$ at the Mumfort Island, Piankatank River, and Spider Crab Bay sites, respectively. Any positive bias in sediment height affecting our disturbance depth inferences would result in conservative (shallow) estimates of disturbance depth, 
although the magnitude of any potential bias seems small relative to the $1 \mathrm{~cm}$ resolution of our tracer particle layers.

Our measurements of sediment disturbance, deposition, and erosion are generally consistent with literature values within and outside vegetated areas (Koch et al. 2006). These changes can be rapid, influencing decimeters of sediment in a few hours (Paling et al. 2003), and are capable of removing deeply rooted plants and causing large-scale landscape changes (Koch et al. 2006). Our data show that sediment re-suspension and erosion clearly have the potential to remove developing seedlings, especially at early stages before their rhizomes and root hairs are able to locally stabilize sediments (Titus \& Hoover 1991). Variability in these processes was seen over spatial scales of tens of meters. Within experimental plots, we observed accretion of up to $3 \mathrm{~cm}$ and erosion to $1.5 \mathrm{~cm}$. However, our permanent depth poles suggested that accretion could be as high as $12.5 \mathrm{~cm}$ over $6 \mathrm{mo}$, and observations of rhizome layer depth from previous experiments have also shown high accretion levels (R. Orth unpubl. data).

\section{CONCLUSIONS}

This wintertime experiment showed that seed germination is not the primary factor limiting Zostera marina seedling establishment in unvegetated, sandy sediments in our region. Instead, we showed that germination rates are generally high, but many developing seedlings at or near the sediment surface are subsequently lost due to sediment disturbance, while seedlings developing from buried seeds have a higher retention rate. Winter conditions and seed burial depth may provide an important piece of the puzzle regarding the low seedling establishment rates in previous seed experiments. Investigating the factors that affect seed burial depth such as bioturbation (Dumbauld \& Wyllie-Echeverria 2003, Meysman et al. 2006) and seed morphology (Benvenuti 2007), as well as the sedimentary characteristics of sites that enhance seedling retention, may be key to understanding the colonization potential of different seagrass species, as well as to the development of optimal restoration strategies.

Physical disturbance of developing seedlings may also be an important process influencing the natural dynamics of Zostera marina meadows due to the potential feedback of an existing seagrass canopy on seedling success. Seagrass canopies decrease wave energy reaching the sediment-water interface, and consequently reduce sediment resuspension (Koch et al. 2006, Hansen \& Reidenbach 2012, this TS). Higher initial success of seedlings might therefore be expected within established canopies, although experiments in Ruppia maritima canopies found no enhancement for surface seeds (Marion \& Orth 2010b), and seedlings establishing within $Z$. marina canopies subsequently face light competition from adult plants (Olesen 1999). We suggest that $Z$. marina is more likely than $R$. maritima to reduce wave and current energy within the meadow, enhancing seedling establishment within sand gaps and creating a positive feedback cycle for meadow persistence. Conversely, the increased potential for seedling loss due to sediment disturbance in regions where the $Z$. marina canopy has been lost may create a negative feedback cycle, maintaining an unvegetated state by limiting recolonization after canopy loss. Further investigation of seedling success relative to existing canopies is necessary to understand the importance of these potential feedbacks for meadow persistence and recovery.

Acknowledgements. We are indebted to our field crew, C. Holbert and M. Wunderly, who worked to get accurate counts of seedlings under some of the harshest winter field conditions. We appreciate the financial assistance of National Oceanic and Atmospheric Administration Grant No. NA07NMS4570345; Virginia Marine Resources Commission's Recreational Fishing License Fund; The Nature Conservancy; and private grants from Norfolk-Southern, and the Keith Campbell Foundation for the Environment. This is contribution no. 3210 from the Virginia Institute of Marine Science.

\section{LITERATURE CITED}

Ackerman J (2006) Sexual reproduction of seagrasses: pollination in the marine context. In: Larkum AWD, Orth RJ, Duarte CM (eds) Seagrasses: biology, ecology and conservation. Springer, Dordrecht, p 89-109

Benvenuti S (2007) Natural weed seed burial: effects of soil texture, rain and seed characteristics. Seed Sci Res 17: 211-219

Christian CE, Stanton ML (2004) Cryptic consequences of a dispersal mutualism: seed burial, elaiosome removal, and seed bank dynamics. Ecology 85:1101-1110

> Churchill AC (1983) Field studies on seed germination and seedling development in Zostera marina L. Aquat Bot 16: 21-29

> Churchill AC, Nieves G, Brenowitz AH (1985) Flotation and dispersal of eelgrass seeds by gas bubbles. Estuaries 8: 352-354

> Clark CJ, Poulsen JR, Levey DJ, Osenberg CW (2007) Are plant populations seed limited? A critique and metaanalysis of seed addition experiments. Am Nat 170: $128-142$

Dumbauld BR, Wyllie-Echeverria S (2003) The influence of 
burrowing thalassinid shrimps on the distribution of intertidal seagrasses in Willapa Bay, Washington, USA. Aquat Bot 77:27-42

Fishman JR, Orth RJ (1996) Effects of predation on Zostera marina seed abundance. J Exp Mar Biol Ecol 198:11-26

Granger SL, Traber MS, Nixon SW (2000) The influence of planting depth and density on germination and development of Zostera marina L. seeds. Biol Mar Mediterr 7: $55-58$

Green EP, Short FT (eds) (2003) World atlas of seagrasses. University of California Press, Berkeley, CA

> Handley RJ, Davy AJ (2002) Seedling root establishment may limit Najas marina L. to sediments of low cohesive strength. Aquat Bot 73:129-136

> Hansen JCR, Reidenbach MA (2012) Wave and tidally driven flows in eelgrass beds and their effect on sediment suspension. Mar Ecol Prog Ser 448:271-287

Harper JL (1977) Population biology of plants. Academic Press, London

Harwell MC, Orth RJ (2001) Influence of a tube-dwelling polychaete on the dispersal of fragmented reproductive shoots of eelgrass. Aquat Bot 70:1-8

Harwell MC, Orth RJ (2002) Long-distance dispersal potential in a marine macrophyte. Ecology 83:3319-3330

> Hulme PE, Borelli T (1999) Variability in post-dispersal seed predation in deciduous woodland: relative importance of location, seed species, burial and density. Plant Ecol 145:149-156

Koch EW, Ackerman JD, Verduin J, van Keulen M (2006) Fluid dynamics in seagrass ecology: from molecules to ecosystems. In: Larkum AWD, Orth RJ, Duarte CM (eds) Seagrasses: biology, ecology and conservation. Springer, Dordrecht, p 193-225

Koch EW, Ailstock MS, Booth DM, Shafer DJ, Magoun AD (2010) The role of currents and waves in the dispersal of submersed angiosperm seeds and seedlings. Restor Ecol 18:584-595

Luckenbach ML, Orth RJ (1999) Effects of a deposit-feeding invertebrate on the entrapment of Zostera marina L. seeds. Aquat Bot 62:235-247

Marion SR, Orth RJ (2010a) Innovative techniques for largescale collection, processing, storage, and dispersal of eelgrass (Zostera marina) seeds. Restor Ecol 18:514-526

Marion SR, Orth RJ (2010b) Factors influencing seedling establishment rates in eelgrass (Zostera marina) and their implications for seagrass restoration. Restor Ecol 18: 549-559

Meysman FJR, Middelburg JJ, Heip CRP (2006) Bioturbation: a fresh look at Darwin's last idea. Trends Ecol Evol

Submitted: May 2, 2011; Accepted: January 19, 2012
21:688-695

Moore KA, Orth RJ, Nowak JF (1993) Environmental regulation of seed germination in Zostera marina L. (eelgrass) in Chesapeake Bay: effects of light, oxygen and sediment burial. Aquat Bot 45:79-91

Olesen B (1999) Reproduction in Danish eelgrass (Zostera marina L.) stands: size-dependence and biomass partitioning. Aquat Bot 65:209-219

> Orth RJ, Moore KA (1983) Chesapeake Bay: an unprecedented decline in submerged aquatic vegetation. Science 222:51-53

Orth RJ, Luckenbach MW, Moore KA (1994) Seed dispersal in a marine macrophyte: implications for colonization and restoration. Ecology 75:1927-1939

> Orth RJ, Fishman JR, Harwell MC, Marion SR (2003) Seed density effects on germination and initial seedling establishment in eelgrass Zostera marina in the Chesapeake Bay region. Mar Ecol Prog Ser 250:71-79

Orth RJ, Moore KA, Marion SR, Wilcox DJ, Parrish DB (2012) Seed addition facilitates eelgrass recovery in a coastal bay system. Mar Ecol Prog Ser 448:177-195

> Paling EI, van Keulen M, Wheeler KD (2003) The influence of spacing on mechanically transplanted seagrass survival in a high wave energy regime. Restor Ecol 11:56-61

Paling EI, Fonseca M, van Katwijk MM, van Keulen M (2009) Seagrass restoration. In: Perillo GME, Wolanski E, Cahoon DR, Brinson M (eds) Coastal wetlands: an integrated ecosystems approach. Elsevier, Amsterdam, p $687-713$

Rasmussen E (1977) The wasting disease of eelgrass (Zostera marina) and its effects on environmental factors and fauna. In: McRoy CP, Helfferich C (eds) Seagrass ecosystems. Marcel Dekker, New York, NY, p 1-51

Setchell WA (1929) Morphological and phenological notes on Zostera marina L. Univ Calif Publ Bot 14:389-452

> Silberhorn G, Orth RJ, Moore KA (1983) Anthesis and seed production in Zostera marina L. (eelgrass) from the Chesapeake Bay. Aquat Bot 15:133-144

> Tanner CE, Parham T (2010) Growing Zostera marina (eelgrass) from seeds in land-based culture systems for use in restoration projects. Restor Ecol 18:527-537

$>$ Titus JE, Hoover DT (1991) Toward predicting reproductive success in submersed freshwater angiosperms. Aquat Bot 41:111-136

> Waycott M, Duarte CM, Carruthers TJB, Orth RJ and others (2009) Accelerating loss of seagrasses across the globe threatens coastal ecosystems. Proc Natl Acad Sci USA 106:12377-12381

Proofs received from author(s): February 9, 2012 